\title{
ISLAMIC EDUCATION SYSTEM AND CHARACTER EDUCATION AT INTEGRAL ELEMENTARY SCHOOL OF LUQMAN HAKIM BOJONEGORO
}

\author{
Siti Ermawati \\ Fakultas Bahasa dan Seni IKIP PGRI Bojonegoro \\ e-mail: ermawati.saja2016@gmail.com
}

\begin{abstract}
This research was conducted at Integral Elementary School of Luqman Hakim Bojonegoro by analyzing its Islamic education system and its implementation in building the students' characters. It employed qualitative approach by descriptive method in a case study type. The data were collected through interview and documentation using method and source triangulation as data validity test. The data analysis technique was interactive analysis method. The research results showed that (1) the Islamic education system applied at this school was combining diniyah and academic achievement. This elementary school emphasizes on Al Qur'an and science, (2) the implementation of Islamic education in building the students' characters is actualized in the classroom learning activity (combining Al Qur'an and science), the teachers' exemplary in educating the students during the teaching process both inside and outside the classroom, one of which is by having extracurricular that implementing the character education values.
\end{abstract}

Keywords: Islamic Education System, Character Education.

\begin{abstract}
Abstrak
Penelitian ini bertujuan untuk menganalisis sistem pendidikan Islam dan implementasinya dalam membentuk karakter siswa pada SD Integral Luqman Hakim Bojonegoro. Penelitian ini menggunakan pendekatan kualitatif dengan metode deskriptif, sedangkan jenis penelitian ini adalah studi kasus. Pengumpulan data penelitian dilakukan melalui wawancara dan dokumentasi. Uji validitas data yang digunakan adalah trianggulasi metode dan trianggulasi sumber. Sementara itu, teknik analisis data yang digunakan adalah metode analisis interaktif. Hasil penelitian menunjukkan bahwa (1), Sistem pendidikan Islam yang diterapkan di SD Integral Luqman Hakim, yakni dengan memadukan pendidikan Islam yang unggul dalam diniyah dan unggul dalam akademik, SD Integral luqman hakim mengedepankan pembelajaran yang berbasis Al-qur'an dan sains (2) Implementasi pendidikan Islam dalam membentuk karakter siswa di SD Integral luqman hakim terwujud dalam kegiatan pembelajaran dikelas (perpaduan Al-qur'an dan sains), serta keteladanan pengajar dalam mendidik siswa - siswi yang tidak ada diwujudkan dalam pembelajaran di dalam kelas dan diluar kelas, misalnya seperti ekstrakulikuker yang mengimplentasi nilai-nilai pendidikan karakter.
\end{abstract}

Kata Kunci: Sistem, Pendidikan, Karakter

\section{INTRODUCTION}

One of national education objectives in Indonesia is building students' characters. The article 1 of Indonesian Law of National Education System in 2003 stated that the goal of national education is developing the student's potential to have intelligence, personality, and good moral. In this case, education creates Indonesian people who are not only smart but also have noble and religion noble characters (Pranowo, 2012). Islamic education means education based on Islam which is understood, developed, and formulated from precept and fundamental values of $\mathrm{Al}$ Qur'an and Al Hadist as the main sources.

The essence of Islamic education is on the basic concept from the 
understanding and development of $\mathrm{Al}$ Qur'an and As Sunnah. Meanwhile, its operational concept can be understood, analyzed, and developed from the processes of civilizing and inheritance of culture, religion, and Islamic civilization from generation to generation. In practical concept, Islamic education is understood, analyzed, and developed from the process of nurturing and educating Moslem personality on every generation during the history of Moslem (Muhaimin, 2008)

To Moslem, religion becomes the main fundamental in educating children through education facilities. By implanting religious values since childhood, they will have good behavior and personality when they grow mature. In other words, Islamic education is an effort to build child personality based on Islam precept. It can also be defined as an effort to think, decide, act, and responsible based on Islam values (Zuhairini, 2004).

Islam education is a part of Moslem life system and life goal. Therefore, it must be positioned as a medium to achieve life goal. Islam education is responsible for not only developing students' potentials but also directing and building students' characters based on human life goal and Islamic values (Asifudin, 2010).

Islamic education means attempts to educated Islamic precept and values so as to be somebody's way of life (Muhaimin, 2010). Thus, educators must understand the importance of Islamic education as a means of building students' characters as it has values which can be implemented in daily life.

Education belongs to conscious and systematical efforts in developing students' potentials. Education refers to the attempts of people and country in preparing the young generation for better living in the future. This continuity can be noticed from the inheritance of culture and character owned by people and country. Therefore, education can be defined as the process of inheriting nation's culture and characters to young generation as well as the process of developing culture and nation's characters to improve the life quality of people and nation in the future. During the process of educating culture and nation's characters, students will actively develop their potentials, do internalization, and deepen values to be their personality used for joining the community, developing people's welfare, and improving dignified country's life. (Hasan, 2010)

Nowadays, education must be balanced by knowledge and religious science as both belong to one unit which is closely related from one to another. The moral degradation among students is more or less influenced by the advancement of technology. Diverse information can easily be accessed by people. Many mass media publish news reflecting moral degradation among students such as brawling, bullying, raping, and free dating. These examples of moral degradation have proved that implanting characters to students is very crucial (Mardikarini, 2016).

According to Pala (2011: 23), character education is national movement to create ethical and responsible school by giving model and good character teaching on universal values. This belongs to conscious proactive efforts carried out by school, region, and status for implanting important values to students such as care, honest, fair, and respectful to themselves and others. Many people think that character education is only related to educating human personality. In fact, character education is connected to not only human personality but also academic achievement. Character education at school involves all components of school such as curriculum, learning and assessment process, relationship quality, school 
management, activity implementation, management, and infrastructure empowerment, financial support, and work ethic of all people and environment at school (Citra, 2012:).

Character education aims at developing values for building nation characters of Pancasila such as (1) developing students' potentials so as to have good heart, good thought, and good behavior; (2) building characters of Pancasila; (3) developing citizens' potential to be confident, proud of nation and country, and love each other.

The education of culture and nation character functions for: (1) Development; developing students' potentials to be people with good behavior particularly for students who have had attitude and behavior reflecting culture and nation's characters, (2) Improvement; strengthening the role of national education to be responsible in developing students' potentials so as to be more dignified, (3) Filtering; selecting the Indonesian culture and others which are not suitable with the dignity of cultural values and nation characters (Hasan, 2010).

The recent phenomenon showed that many parents do not pay attention to their children potentials. Most of them oblige their children to join additional course out of school hours so that they are clever in mathematics, foreign language, and so forth. The indicator of smart is the acquisition of science without religious knowledge or character nurturing. Consequently, nowadays, students are less appreciative to others, less polite to older people (parents). On the other side, there is perception stating that good or bad character or moral of students becomes the responsibility of religion and civics teachers.

\section{METHODOLOGY}

This research was carried out at the Integral Elementary School of Luqman Hakim, Bojonegoro. Qualitative approach with descriptive method was employed in this case study. The data were collected through interview and documentation. The informants included the headmaster and teachers in this school. The data validity was tested by triangulations of method and sources. Meanwhile, the data analysis technique employed interactive analysis method.

\section{FINDINGS AND DISCUSSION}

\section{Islamic Education System at Integral Elementary School of Luqman Hakim}

Islamic Education System covers four main things such as the goal, curriculum, method, and evaluation of education. Integral Elementary School of Luqman Hakim is a religion-based school which forwarding diniyah education (excellent in Al Qur'an), character (moral), and academic achievement. This school has commitment to be Islamic institution which is preeminent in diniyah and academic.

The researcher discussed about the system of Islamic Education at Integral Elementary School of Luqman Hakim. Wahid, the headmaster of this school (2017) has stated that the purpose of Islamic education at Integral Elementary School of Luqman Hakim is to create students who are preeminent in Al Qur'an and academic as well as have praiseworthy character (moral).

The curriculum of this school is almost the same with the one written by Ministry of Education and Culture called the 2013 Curriculum or Kurikulum 2013 (K13) and School-based Curiculum or Kurikulum Tingkat Satuan Pendidikan (KTSP). K13 is implemented to grades 1-4, while grades 5-6 use KTSP. The mid-test and final-test are conducted based on the 
schedule issued by the Ministry of Education and Culture.

The diniyah curriculum is the typical curriculum of Integral Elementary School of Luqman Hakim. It belongs to specific curriculum for teaching Al Qur'an. To support the curriculum load, a system of full day school is offered in which diniyah begins after Dhuhur pray. This extra time is used for teaching local load subjects such as Al Qur'an and Arabic. There are three classes in diniyah curriculum i.e. grade 1 (grades $1 \& 2$ ), grade 2 (grades $3 \& 4$ ), and grade 3 (grades $5 \& 6$ ) foe each Al Qur'an and tajwid class. The diniyah curriculum has special references according to the school vision and mission. The reference books are written by the teachers (ustad/ustazah) from this school so that their languages are easy to be understood by the students.

The learning system in diniyah curriculum is not limited only on the teaching phase but also on evaluation phase. Every the end of semester, openedtest is carried out by ustad/ustazah to their students including tests of tajwid and ghorib. The oral test of ghorib is carried out by outsider or from the centre of foundation. The students in take-turn will be tested by one examiner and witnessed by their parents. Thus, it can be clearly noticed whether the student are fluent or not. The sanction for those who are not fluent in ghorib is left behind or they cannot go the further grade.

Integral Elementary School of Luqman Hakim prioritizes Al Qur'an in teaching and learning. The students must be able to read and write Al Qur'an well, implement its content in daily life such as praying before eating, forbid eating while standing, throwing rubbish at the dustbin, cooperating each other, and so on. Besides, aqidah value becomes the other priority. All school subjects use Al Qur'an approach.
Every student who learns all school subjects is told that Al Qur'an is the source of knowledge. Consequently, the effects of knowledge must be returned to Al Qur'an. In other words, a smart human is caused by Allah.

The method applied at Integral Elementary School of Luqman Hakim is almost same as the other schools. According to Hidayati (2017), one of teachers from this school, the method appled in the classroom is adjusted with the teaching and learning materials. The students of this school are so active that the teachers must vary the teching method. Generally the teachers employ expository, discussion, and question-answer methods. During the teaching process of science, natural approach is applied. It uses nature as the learning media and learning props as this school is located closely to nature. Natural approach covers three aspects namely alamiah, islamiyah, and ilmiah. Alamiah means using nature as the learning media, Islamiyah means integrating Islamic values in learning, and ilmiah means using props as learning media (LCD and so forth).

Evaluation is a process to describe, collect, and present useful information for considering decision making. The domains of evaluation involve cognitive, affective, and psychomotor. In terms of cognitive domain, the test is given in oral, multiple choice, objective essay, non-objective essay or free essay, short answer/essay, matching, portofolio, and performance (Syahputri, 2015). In the context of affective, the evaluation is connected to attitude and passion/motivation domains. The psychomotor is evaluated in skill or ability to act after students get learning experience (Sukriah, 2013).

Evaluation implemented at Integral Elementary School of Luqman Hakim is same as that of other schools in general 
such as written and oral tests in the form of daily test, mid-test, and final-test. The evaluation is based on the Competence Standard and Basic Competence of each school subject. Oral evaluation is applied for school subjects of Arabic, English, and local load (Al Qur'an). According to Hidayati (2017), evaluation usually implemented is question-answer at the end of material delivery. She assumed that students are difficult to fully concentrate on the teaching material. Therefore, to know the success of learning, this evaluation is needed.

\section{Implementation of Islamic Education at Integral Elemantary School of Luqman Hakim in Building Student's Character}

Implementation is an act or conduct of a plan arranged in good and detail formulation. Implementation is carried out when the plan is matured (Angreiny, 2012). Building character is like shaping precious stone or hard iron. As a result, character is defined as typical sign or behavior pattern (Bohlin, Farmer, \& Ryan, 2001). Planning and implementing character education is carried out by headmaster, teachers, and counselors (educator) simultaneously as single community of education in curriculum implementation. The integration of character values in every discussion of school subject is compulsory.

Character education must begin in the early age. The support from family must be prioritized. There must be suitability between school and parents. At Integral Elementary School of Luqman Hakim, character building has been launched in the education system particularly in the classroom teaching activity. This school uses Al Qur'an as the main priority of learning. Through Al Qur'an learning, students implement its contents in daily lives. It is expected that their daily behavior will in line with Al Qur'an guideline. Indirectly, characters have been built in the classroom learning activity.

In Islamic education system, the values of character education have been formulated. By a learning model which refers to Al Qur'an, the values of character education automatically include. For instance, the concept of integral education stated in the vision and mission of this school means integral education for all school subjects. The existence of moral value-diniyah education-life skill supports character education. Active and studentscentered learning is carried out at school, class, and society.

To investigate the achievement of character education, school and class indicators will assist headmaster, teachers, and other components in planning, implementing, and evaluating school as an institution of character education agent. Table 1 describes the implementation of character education at Integral Elementary school of Luqman Hakim:

Table 1. The Implementation of Character Education

\begin{tabular}{|c|c|c|c|c|}
\hline Value & Description & & School Indicator & Class Indicator \\
\hline Religious & $\begin{array}{l}\text { Attitude and behavior of } \\
\text { obedience in conducting } \\
\text { religion precept, tolerate } \\
\text { to other religion precept, } \\
\text { and live harmoniously } \\
\text { with other religion } \\
\text { followers. }\end{array}$ & $\begin{array}{l}0 \\
0\end{array}$ & $\begin{array}{l}\text { Celebrate religious } \\
\text { great days. } \\
\text { Have pray facilities. } \\
\text { Give opportunity to } \\
\text { all students to pray. }\end{array}$ & $\begin{array}{ll}\circ & \text { Pray before learning. } \\
\circ & \text { Specific learning of Al- } \\
& \text { qur'an, Tajwid, and } \\
& \text { Ghorib. } \\
\circ & \text { Give opportunity to all } \\
& \text { students to pray. }\end{array}$ \\
\hline
\end{tabular}




\begin{tabular}{|c|c|c|c|c|c|}
\hline Honest & $\begin{array}{l}\text { Behavior reflecting } \\
\text { honesty in utterance, } \\
\text { attitude, and task. }\end{array}$ & ○ & $\begin{array}{l}\text { Educate by giving } \\
\text { examples of good } \\
\text { habituation. } \\
\text { Educate by } \\
\text { implementing } \\
\text { Rosulullah saw } \\
\text { personality. }\end{array}$ & $\begin{array}{l}\circ \\
\circ\end{array}$ & $\begin{array}{l}\text { Educate patiently. } \\
\text { Give examples of honest } \\
\text { habituation. }\end{array}$ \\
\hline Tolerate & $\begin{array}{l}\text { Attitude and behavior of } \\
\text { appreciating diversity of } \\
\text { religion, tribe, ethic, } \\
\text { opinion, attitude, and } \\
\text { action of others who } \\
\text { different from him/her. }\end{array}$ & ○ & $\begin{array}{l}\text { Appreciate other } \\
\text { opinion. }\end{array}$ & ○ & $\begin{array}{l}\text { Give opportunity to all } \\
\text { students to argue. }\end{array}$ \\
\hline Discipline & $\begin{array}{l}\text { Behavior of showing } \\
\text { orderliness and } \\
\text { obedience based on the } \\
\text { rule. }\end{array}$ & ○ & $\begin{array}{l}\text { Implement and obey } \\
\text { the written and oral } \\
\text { rule. }\end{array}$ & ○ & $\begin{array}{l}\text { Come in the class on } \\
\text { time. } \\
\text { Pray at the beginning of } \\
\text { praying time. }\end{array}$ \\
\hline Work hard & $\begin{array}{l}\text { Behavior showing } \\
\text { seriousness in } \\
\text { overcoming learning } \\
\text { and task obstacles as } \\
\text { well as accomplishing } \\
\text { task well. }\end{array}$ & $\circ$ & $\begin{array}{l}\text { Give additional time } \\
\text { for students who } \\
\text { need more learning } \\
\text { such as extra } \\
\text { course/guidance and } \\
\text { so on. }\end{array}$ & $\circ$ & $\begin{array}{l}\text { Give wide opportunity to } \\
\text { ask-answer/discussion to } \\
\text { students. }\end{array}$ \\
\hline Creative & $\begin{array}{l}\text { Think and do something } \\
\text { to produce new way or } \\
\text { result from something } \\
\text { the students own. }\end{array}$ & ○ & $\begin{array}{l}\text { Facilitate by using } \\
\text { media to attract and } \\
\text { grow students' } \\
\text { creativities. }\end{array}$ & ○ & $\begin{array}{l}\text { Practice skill (students' } \\
\text { works). }\end{array}$ \\
\hline Autonomous & $\begin{array}{l}\text { Attitude and behavior of } \\
\text { independent in finishing } \\
\text { tasks. }\end{array}$ & ० & $\begin{array}{l}\text { Give autonomous } \\
\text { habituation in } \\
\text { accomplishing tasks } \\
\text { Train self-regulating } \\
\text { through extra } \\
\text { activities (OPLH). }\end{array}$ & ○ & $\begin{array}{l}\text { Accomplish tasks in the } \\
\text { classroom independently. }\end{array}$ \\
\hline Democratic & $\begin{array}{l}\text { Think, behave, and act } \\
\text { by considering others' } \\
\text { equal rights and duty. }\end{array}$ & ○ & $\begin{array}{l}\text { Habituation of } \\
\text { appreciating others. }\end{array}$ & ○ & $\begin{array}{l}\text { Give opportunity to } \\
\text { students to argue. }\end{array}$ \\
\hline Curious & $\begin{array}{l}\text { Attitude and behavior to } \\
\text { know more in-depth of } \\
\text { something the students } \\
\text { learn, see, and hear. }\end{array}$ & ○ & $\begin{array}{l}\text { Open opportunity to } \\
\text { ask }\end{array}$ & ○ & $\begin{array}{l}\text { Facilitate students for } \\
\text { question-answer session. }\end{array}$ \\
\hline Peace loving & $\begin{array}{l}\text { Attitude, words, and } \\
\text { action causing others } \\
\text { feel happy and safe. }\end{array}$ & ○ & Open for any critics. & ○ & $\begin{array}{l}\text { Habituation of having } \\
\text { good and polite behavior } \\
\text { and statement } \\
\text { particularly to older } \\
\text { people and others. }\end{array}$ \\
\hline Reading & Habit in allocating time & 0 & Facilitate a library & 0 & Promote reading habit \\
\hline
\end{tabular}




\begin{tabular}{|c|c|c|c|c|c|}
\hline habit & $\begin{array}{l}\text { to read various texts } \\
\text { containing virtues. }\end{array}$ & & $\begin{array}{l}\text { as learning } \\
\text { media/source. }\end{array}$ & & $\begin{array}{l}\text { program (including } \\
\text { reading Al Qur'an). }\end{array}$ \\
\hline $\begin{array}{l}\text { Environmen } \\
\text { tally } \\
\text { friendly }\end{array}$ & $\begin{array}{l}\text { Attitude and behavior to } \\
\text { prevent destruction on } \\
\text { environment and } \\
\text { develop efforts in } \\
\text { repairing natural } \\
\text { destruction. }\end{array}$ & O & $\begin{array}{l}\text { Get award of } \\
\text { Adiwiyata School in } \\
2013 .\end{array}$ & O & $\begin{array}{l}\text { Use environment as } \\
\text { learning media/means. }\end{array}$ \\
\hline Responsible & $\begin{array}{l}\text { Attitude and behavior to } \\
\text { do tasks and obligation } \\
\text { to himself/herself, } \\
\text { society, environment } \\
\text { (nature, social, and } \\
\text { culture), country, and } \\
\text { God. }\end{array}$ & o & $\begin{array}{l}\text { Habituation of } \\
\text { responsibility. } \\
\text { Habituation of } \\
\text { throwing rubbish at } \\
\text { the dustbin. }\end{array}$ & ○ & $\begin{array}{l}\text { Try to be responsible in } \\
\text { finishing task. }\end{array}$ \\
\hline
\end{tabular}

The actualization of character
education carried out by Integral Elementary School of Luqman Hakim sometimes encounters obstacles such as diverse opinions between school and parents. Therefore, there must be suitability between both. Family is the place where children learn about life. Family becomes the first place the children interact with. Thus, family gives great influence to the growth and development of children (Fathiyaturrohmah, 2014). Formal education must be supported by the role of family. The goal of formal education will not be manifested without cooperation from parents. Wahid (2017) stated that routine meeting among foundation, teachers, and parents functions for aligning differences and actualizing together for better education.

\section{CONCLUSION}

The Islamic educational system at Integral Elementary School of Luqman Hakim was applied by combining Diniyah and academic loads. This school implemented Al Qur'an and science-based learning. Islamic education was implemented in building students' characters through indoor learning (combining Al Qur'an and science) and teachers' exemplary indoor and outdoor of class, such as through extracurricular.

\section{RECOMMENDATION}

The research results reported that there were some obstacles encountered by teachers in implementing character education such as (a) the students habituation of attitude and behavior as well as their consistence when they are at school and at home, (b) keeping the students discipline at school and at home, (c) the incompatibility opinion between teachers and parents. These obstacles can be overcome by: (1) Make agreement between school and parents in controlling attitude, behavior, and kid consistence, (2) cooperate with each other so that the children become discipline in time, (3) give guidance and explanation to parents about the school vision and mission that must be actualized together. 


\section{REFERENCES}

Basri, H. (2010). Filsafat Pendidikan Islam. Bandung: Pustaka Setia.

Bohlin, E. K., Deborah, F, \& Kevin, R. (2001). Building Character in School Resource Guide. San Fransisco: Jossey Bass.

Citra, Y. (2012). Pelaksanaan Pendidikan Karakter dalam Pembelajaran. Jurnal Ilmiah Pendidikan Khusus, 1 (1) : 239. Retrieved on October 17, 2017.

Fathiyaturrohmah. (2014). Ayat-Ayat tentang Peranan Ibu dalam Pendidikan Anak. Jurnal Elementary, 2 (11).

Irma, A. (2012)/ Pengertian Implementasi Menurut Para Ahli. Available on http://el-

kawaqi.blogspot.co.id/2012/12/penge rtian-implementasi-menurutpara.html. Accessed on October 17, 2017.

Muhaimin. (2008). Paradigma Pendidikan Islam. Forth Edition. Bandung: PT Remaja Rosdakarya.

Muhaimin. (2010). Pengembangan kurikulum pendidikan Islam. Jakarta: Raja Grafindo.

Pala, A. (2011). The Need for Character Education. International Journal of Social Sciences and Humanity Studies, 3 (2) : 23-32.
Pranowo, D. D. (2013). Implementasi Pendidikan Karakter Kepedulian dan Kerjasama Mata Kuliah Keterampilan Berbicara Bahasa Prancis dengan Metode Bermain Peran. Jurnal Pendidikan Karakter, 3 (2) : 218-230. Available on http://staff.uny.ac.id/sites/default/file s/penelitian/Dr.\%20Dwiyanto\%20Dj oko\%20Pranowo,\%20M.Pd./JURNA L\%20PENDIDIKAN\%20KARAKT ER.pdf.

Putri, M, S. (2015). Ranah Penilaian, Kognitif, Afektif dan Psikomotorik (Evaluasi). Available on http://meldasyahputri.blogspot.co.id/ 2015/11/ranah-penilaian-kognitifafektif-dan.html. Accessed on October 17, 2017.

Said, H.H. (2010). Bahan Pelatihan: Pengembangan Pendidikan Budaya dan Karakter Bangsa. Jakarta: Curriculum Center, Research and Development Agency, Ministry of National Education.

Sukriah. (2013). Dengan Ranah Kognitif, Afektif dan Psikomotorik. Available on http://mnnbcvbnzxcv.blogspot.co.id/. Accessed on October 17, 2017.

Zuhairini. (2004). Filsafat Pendidikan Islam. Third Editon. Jakarta: Bumi Aksara. 